\title{
Follow-up of Cancer Patients by Family Health Workers ${ }^{1}$
}

\author{
Giovana Paula Rezende Simino² \\ Cláudia Benedita dos Santos ${ }^{3}$ \\ Silvana Martins Mishima ${ }^{4}$
}

This descriptive and quantitative study identified and analyzed follow-up actions developed by workers of 13 Family Health Teams (FHT) for cancer patients in a city in the Southeast of Brazil. A questionnaire validated by seven experts was applied to 101 workers. The results indicated that $80.2 \%$ of workers were aware of the existence of cancer patients in the FHT scope area; $13.9 \%$ were aware of the total number of cancer patients; and $63.3 \%$ delivered care to these patients; home visits were carried out by $93.1 \%$; and $69 \%$ discussed cases during FHT meetings. Emotional support was the most frequent action among those offered by workers to caregivers. As to the joint work developed within the service network, $46.5 \%$ reported that there are no counter-referrals. The conclusion is that follow-up is not systematized; there are needs and possibilities within the Family Health Strategy for workers to follow-up with cancer patients and their caregivers.

Descriptors: Family Health Program; Primary Health Care; Neoplasms; Continuity of Patient Care.

Escola de Enfermagem de Ribeirão Preto, Universidade de São Paulo, WHO Collaborating Centre for Nursing Research Development, SP, Brazil:

${ }^{1}$ Paper extracted from Master's Thesis "Acompanhamentos de usuários com câncer e seus cuidadores por trabalhadores de equipes de saúde da família: possibilidades e desafios". Supported by CNPq Process \#301443/2006-8.

${ }^{2}$ RN, Master's Student. E-mail: gsimino@yahoo.com.br.

${ }^{3}$ Ph.D. in Statistics, Associate Professor. E-mail: cbsantos@eerp.usp.br.

${ }^{4}$ RN, Ph.D. in Nursing, Full Professor. E-mail: smishima@eerp.usp.br.

Corresponding Author:

Silvana Martins Mishima

Universidade de São Paulo. Escola de Enfermagem de Ribeirão Preto.

Av. dos Bandeirantes, 3900

Bairro Monte Alegre

CEP: 14040-902 Ribeirão Preto, SP, Brasil

E-mail: smishima@eerp.usp.br 


\section{Acompanhamento de usuários, portadores de câncer, por trabalhadores da saúde da família}

Objetivou-se, aqui, identificar e analisar as ações de acompanhamento desenvolvidas pelos trabalhadores de 13 Equipes de Saúde da Família (ESF) aos usuários portadores de câncer, em município do Sudeste do Brasil. Trata-se de estudo descritivo, com abordagem quantitativa. Utilizou-se questionário validado por sete juízes. Foram sujeitos da pesquisa 101 trabalhadores. Verificou-se que $80,2 \%$ dos trabalhadores conheciam a presença de usuários portadores de câncer na área de abrangência da ESF, 13,9\% conheciam o total dos usuários, $63,3 \%$ realizam atendimentos; a visita domiciliar é realizada por $93,1 \%$ dos trabalhadores e $69 \%$ realizam discussão do caso em reuniões da ESF. $O$ apoio emocional ao cuidador é a ação mais frequente dentre aquelas ofertadas pelos trabalhadores ao cuidador. Em relação à articulação da rede de serviços, 46,5\% dos trabalhadores referiram não haver contrarreferência. Concluí-se existir necessidades e possibilidades nas ESFs para realizar o acompanhamento a esses usuários e seus cuidadores, sendo o acompanhamento realizado de modo não sistematizado.

Descritores: Programa Saúde da Família; Atenção Primária à Saúde; Neoplasias; Continuidade da Assistência ao Paciente.

\section{Acompañamiento de pacientes portadores de cáncer por trabajadores de equipos de la salud de la familia}

Se objetivó identificar y analizar las acciones de acompañamiento desarrolladas por los trabajadores de 13 Equipos de Salud de la Familia (ESF), de los pacientes portadores de cáncer en un municipio del Sureste de Brasil. Se trata de un estudio descriptivo con abordaje cuantitativo. Se utilizó un cuestionario validado por siete jueces. Fueron sujetos de la investigación 101 trabajadores. Se verificó que: 80,2\% de los trabajadores conocían la presencia de pacientes portadores de cáncer en el área de influencia de la ESF; 13,9\% conocían el total de los pacientes, 63,3\% realizaban atenciones; la visita domiciliar eran realizadas por $93,1 \%$ de los trabajadores y $69,0 \%$ realizaban discusiones del caso en reuniones de la ESF; y, el apoyo emocional al cuidador es la acción más frecuente entre aquellas ofrecidas por los trabajadores al cuidador. En relación a la articulación de la red de servicios, $46,5 \%$ de los trabajadores refirieron no haber contra referencia. Se concluye que existen necesidades y posibilidades en las ESF para realizar el acompañamiento a estos clientes y a sus cuidadores, siendo que este acompañamiento es realizado de modo no sistematizado.

Descriptores: Programa de Salud Familiar; Atención Primaria de Salud; Neoplasias; Continuidad de la Atención al Paciente.

\section{Introduction}

Cancer is considered a Public Health problem that affects people in different age ranges, social classes and both genders. It is the second leading cause of death in developed countries and the third in developing countries; it is estimated that it is accountable for $12.6 \%$ of total deaths worldwide. This estimate is higher than that for deaths caused by HIV/AIDS, tuberculosis and malaria combined in the world(1).

A total of 466,630 new cases were estimated in 2007(2) for 2008 and 2009: 231,860 among men and 234,870 among women. The most common tumors were estimated to be: non-melanoma skin cancer $(115,000)$, breast cancer $(49,000)$, prostate $(49,000)$, lungs $(27,000)$, cervical cancer $(19,000)$, and colorectal $(14,000)^{(2)}$. This scenario certainly indicates the importance of cancer in the current context of healthcare both in terms of its impact on the population's morbidity and mortality profile and also in relation to the qualification necessary for professionals to deal with the disease and organization of services to provide care.

The Brazilian Ministry of Health issued decree No. $2.439 / G M$, on December $8^{\text {th }} 2005$, instituting a national 
policy for cancer control [Política Nacional de Atenção Oncológica-PNAO], which determines that care provided to cancer patients includes primary to specialized care of medium and high complexity so that actions of promotion, prevention, diagnosis, treatment, rehabilitation and palliative care are included. Hence, it determines that care is organized by levels of hierarchy, establishing flows of referral and counter-referral, ensuring integral access and care(3).

The decree establishes that Basic Health Care $(\mathrm{BHC}) *$, including Basic Health Units and Family Health Teams (FHT), is responsible for developing actions directed to both the individual and collective focusing on health promotion and cancer prevention, as well as early diagnosis and support for tumor therapy, palliative care and clinical actions for the follow-up of patients undergoing treatment. It also indicates the need to share information through information subsystems with the purpose of using them in health promotion. This decree also emphasizes the need to develop specialized human resources and promote permanent education programs to prepare professionals involved with the implementation and deployment of this policy ${ }^{(3)}$.

The Family Health Program (FHP) was initially implemented in Brazil in 1994 to support the Community Health Agents Program. In its initial formulation, this program was directed to actions of the promotion, protection and recovery of health of individuals and family members in all age ranges and health conditions in an integral and continuous manner, with a central focus on the family in its context of life in a specific territory ${ }^{(4)}$. Gradually, the Family Health Program lost its status as a program and has been considered a strategy to reorganize $\mathrm{BHC}$ in Brazil according to the Primary Health Care (PHC) principles(5).

The objective of the Family Health Unit (FHU) is to reorganize health care seeking to overturn the dominant rationale, focused on healing patients in a hospital setting, through a set of interconnected actions within health services in order to include the primary principles of the Single Health System (SUS): universality, decentralization, integrality and participation in the community ${ }^{(4)}$. The $\mathrm{PHC}^{(5)}$ attributes are also expected to be included in the development of this strategy, with the establishment of bonds, longitudinality, action coordination and integrality of care.

Some Brazilian studies stress there are difficulties and challenges in delivering care to cancer patients within the $\mathrm{BHC}$ that are related to the qualifications of professionals - which could be provided through permanent education-, scarcity of material resources, lack of connection among the network services and actions limited to the BHC programs of the Brazilian Ministry of Health ${ }^{(6-10)}$. Considering these aspects, we highlight that the follow-up of the cancer patients in this study is defined according to the PHC attributes, especially longitudinality of care, which is considered the follow-up of individuals in a continuous manner in which bonding is established over time, regardless of the existence of health problems. Any health professional considered a reference for individual and collective access can perform this follow-up(5).

There is a scarcity of studies addressing this subject or thorough analysis of care delivered at this level of care taking into account the Family Health Strategy (FHS). From this perspective, this study can contribute to theoretical and practical reflections in relation to the production of care within the FHS to cancer patients.

This study identifies and analyzes follow-up actions of FHT provided to cancer patients in a large city in the Southeast of Brazil.

\section{Material and Method}

This is a descriptive cross-sectional study. A questionnaire validated for content by seven experts in oncology and public health was used. The instrument addressed workers' demographic information (gender, age, function, schooling, academic degrees, time of work in the current FHS and total time working for Family Health, and experience working with cancer patients previously to the $\mathrm{FHT}$ ) and variables concerning the follow-up of cancer patients (knowledge concerning the existence of cancer patients in the units' scope areas and total number of cancer patients; actions developed with this group - consultation, home visits, support for caregivers, technical and other specific procedures; place where the diagnosis occurs; existence of patients' counter-referral). This study's population is composed of workers (physicians, nurses, dentists, community health agents, nursing auxiliaries and technicians, dentist office assistant) of 13 Family Health teams out of 18 in existence in 2008 in a large city in the Southeast of Brazil, who voluntarily consented to participate in the study after reading and signing free and informed consent forms. All workers were ensured confidentially. The study was submitted to the Research Ethics Committee at the University of São Paulo at Ribeirão Preto, College of Nursing and was approved according to protocol $\mathrm{n}^{\circ} 0785 / 2007$. A total of 118 workers were invited to

* The terminologies 'Primary Health Care' and 'Basic Health Care' have been indistinctly used. In this study, Basic Health Care concerns to the terminology used in Brazil that refers to care processed in basic health services based on the Primary Health Care principles. 
participate in the study and 101 workers consented. The collected data were stored and validated in two separated spreadsheets in the Excel 2003 and later imported into the Statistical Package for Social Science (SPSS) version 14.0 for descriptive data analysis.

\section{Results and Discussion}

Of the 13 studied $\mathrm{FHU}$, five were linked to the University of São Paulo (USP) and eight were functionally dependent on the City Health Department (CHD). For practical purposes, those FHT linked to USP were named $A, B, C, D, E$ and those linked to the $C H D$ were named $F, G, H, I, J, K, L$ and $M$. To facilitate the understanding and presentation of findings, some of the results were grouped according to the health units functional dependence: USP or CHD. Even though it is believed that units linked to USP aggregate an academic component focused on the education of students from different courses in the health fields (medicine, nursing, dentistry, physiotherapy, speech-language-hearing therapy, pharmacy, psychology, occupational therapy), an aspect that is absent in most of the units linked to the $\mathrm{CDH}$ and that could determine different approaches in the way care is processed, there was no intention to statistically compare data among groups.

Therefore, 101 out of 118 workers in the studied FHT participated in the study as presented in Table 1 according to the following distribution: 39 (38.6\%) workers are from five FHT managed by USP and 62 (61.4\%) workers compose eight teams managed by the CHD.

Table 1 shows that all nurses and dentist office assistants consented to participate in the study. The largest percentage of refusal to participate in the study or vacations occurred among dentists; only one out of five dentists responded the invitation to participate.

Table 1 - Numerical distribution of individuals according to profession. Ribeirão Preto, SP, Brazil. 2009

\begin{tabular}{lcc}
\hline Participants / Profession & $\begin{array}{c}\text { FHS total of } \\
\text { workers }\end{array}$ & $\begin{array}{c}\text { Study's total } \\
\text { participants }\end{array}$ \\
\hline CHA & 60 & 54 \\
Nursing auxiliaries & 21 & 16 \\
Nurses & 13 & 13 \\
Physician & 14 & 12 \\
Dentist office assistant & 4 & 4 \\
Nursing technician & 2 & 1 \\
Dentist & 5 & 1 \\
Total & $119^{*}$ & 101 \\
\hline
\end{tabular}

*One worker was transferred from FHU $\mathrm{H}$ to FHU M (He answered the questionnaire at the FHU). That is why 118 workers were considered.
A total of $54 \mathrm{CHA}$ participated in the study and represent $53.5 \%$ of the total studied individuals. The number of $\mathrm{CHA}$ within a $\mathrm{FHT}$ is established according to the minimum composition of a family health team defined by the Ministry of Health(4): the ratio of $\mathrm{CHA}$ within the minimum team is five for one physician, one nurse, one or two nursing auxiliaries or technicians, one dentist, one dentist office assistant. There are no dentists or dentist office assistants in the A, B, C, D and E FHU teams; a dentist from the Basic Health District Unit goes to these units and performs the dental evaluation of their patients. Because these are academic units, this strategy was devised to address issues of team staffing, expanding access to dental care and training of dental professionals.

Workers' ages were predominantly distributed into two age ranges: between 30 and 40 years old with 34 (34.3\%) individuals and between 40 and 50 years old with $30(30.3 \%)$ individuals. The average age was 39.4 years old with $S D=9.1$; the median was 39 years old; the minimum age was 24 years old and the maximum was 59 years old. The coefficient of variation was $23 \%$, which indicates there is no expressive variation among ages. There are no elderly individuals among the participants; $92(91.1 \%)$ were women and nine $(8.9 \%)$ were men. The age distribution reveals a certain "seniority" among the participants of these teams, who are preponderantly female. These findings are somewhat similar to a study developed by the Brazilian Ministry of Health that evaluated FHT in ten large centers ${ }^{(11)}$.

In relation to workers' experience in caring for cancer patients prior to working within the FHT: 10 (25.6\%) workers linked to USP and 15 (24.2\%) linked to the CHD had already cared for cancer patients in previous jobs. The lowest frequencies were identified within the $\mathrm{CHA}$ group. These are professionals with the lowest level of previous experience in the health field, only two (3.7\%) CHA had previous experience; and one (100\%) nursing technician. The professionals with the highest frequencies were: nine (75\%) nurses and nine (60\%) nursing auxiliaries, followed by four (33.3\%) physicians.

In relation to knowledge concerning the total number of cancer patients, $92.3 \%$ of the workers linked to USP and $72.6 \%$ linked to CHD reported being aware of their existence and when reporting the presence of these patients in the scope area of the FHU where they work for, the frequency was nine $(23.1 \%)$ workers in units linked to USP and five (8.1\%) workers in teams linked to CHD. Care provided for cancer patients/family is performed by 29 (74.3\%) workers linked to USP and 35 (56.4\%) linked to CHD as presented in Table 2. 
Table 2 - Distribution of the study's participants according to their knowledge concerning the existence of cancer patients in the units' scope area, total number of these patients and delivered care. Ribeirão Preto, SP, Brazil. 2009

\begin{tabular}{|c|c|c|c|c|c|c|}
\hline \multirow{2}{*}{ Functional Dependence/Cancer patients } & \multicolumn{2}{|c|}{ USP } & \multicolumn{2}{|c|}{ CHD } & \multicolumn{2}{|c|}{ Total } \\
\hline & $\mathbf{N}^{\circ}$ & $\%$ & $\mathbf{N}^{\circ}$ & $\%$ & $\mathbf{N}^{\circ}$ & $\%$ \\
\hline Cancer patients & 36 & 92.3 & 45 & 72.6 & 81 & 80.2 \\
\hline Knowledge concerning the total number of cancer patients in the FHS & 9 & 23.1 & 5 & 8.1 & 14 & 13.9 \\
\hline Deliver care to patients & 29 & 74.3 & 35 & 56.4 & 64 & 63.3 \\
\hline
\end{tabular}

This information is interesting and warrants reflection. Even though cancer is a disease of which follow-up is to be performed by the FHS, as established by the national cancer policy ${ }^{(3)}$, no data are generated for this condition and directed to the FHS or the Ministry of Health, whether through the Information System at the Basic Care service or any other information system used by the BHC services. Data concerning the existence of cancer patients and the total number of these users in the health unit's territory are generated by the teams themselves as a result of the logic and systematic work they develop within the units. No formal records concerning this disease are developed within official information systems, which are the basis for local planning.

Another aspect that deserves attention is the fact that the FHS focuses its work on a defined territory that includes the geopolitical area demarcated by the sociocultural, economic and political context of families that occupy this social space. FHU are expected to know the demographic, social, economic and epidemiological profile of the population under its responsibility in this territory ${ }^{(4)}$. Data in Table 2 indicate that the workers in FHU linked to USP have more knowledge about their territory, perhaps due to the development of their academic project focused on the education of health personnel and the perspective of partnerships with health services aiming to interconnect teaching, research and community services, which is reflected in higher percentages than that of CHD workers concerning knowledge and care provided to cancer patients in their respective territories.

The frequency of workers who reported providing some type of care for cancer patients/ families per unit was: $87.5 \%$ in unit $A, 71.4 \%$ in unit $B, 55.5 \%$ unit $C$, $66.7 \%$ unit $\mathrm{D}, 88.8 \%$ in unit $\mathrm{E}$, which are $\mathrm{FHU}$ linked to USP, and $66.7 \%$ in unit $F, 80 \%$ unit G, $60 \%$ unit $H, 50 \%$ unit $\mathrm{I}, 66.7 \%$ unit $\mathrm{J}, 50 \%$ unit $\mathrm{K}, 25 \%$ unit $\mathrm{L}$, and $80 \%$ in unit $M$.

The percentage of care provided by workers for cancer patients according to the studied health unit is presented in Figure 1. The median is $7.8 \%$; the minimum value is $1.6 \%$ and maximum value $12.5 \%$.

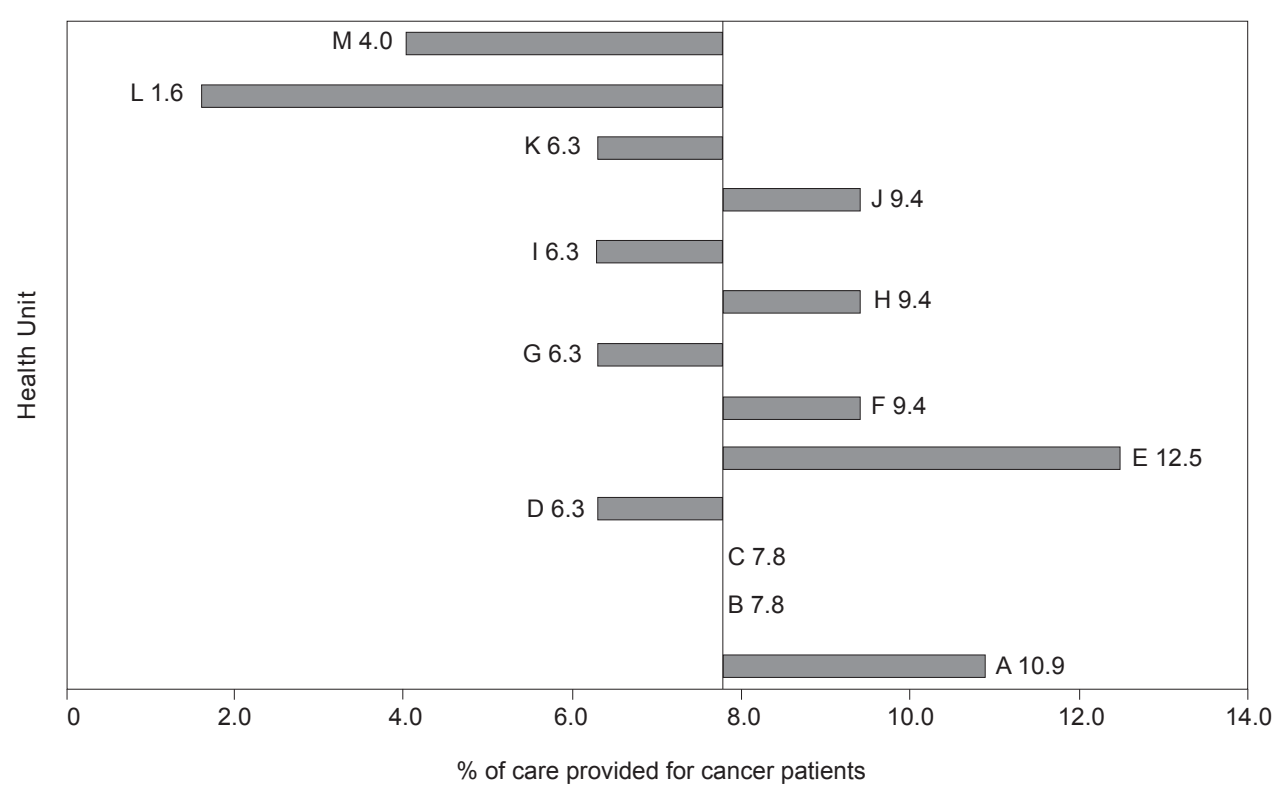

Figure 1 - Percentage of care actions provided by workers for cancer patients in relation to the total of number of actions according to the FHU. Ribeirão Preto, SP, Brazil. 2009 
The median corresponds to the value of two health units linked to USP ( $B$ and $C$ ). Two units linked to USP have a value higher than the median and one unit has a value lower than the median. In relation to units linked to the $\mathrm{CHD}$, three have values higher than the median and five have values lower than the median.

Table 3 shows that among the 64 workers in the FHT who reported providing care for cancer patients: 57 (89.1\%) visit patients at home and 45 (70.3\%) discuss cases of cancer patients in the teams' meetings.

Table 3 - Distribution of individuals according to profession, home visits, discussion concerning situations related to cancer patients/family members during team meetings. Ribeirão Preto, SP, Brazil. 2009

\begin{tabular}{|c|c|c|c|c|}
\hline \multirow{2}{*}{ Activity / Profession } & \multicolumn{2}{|c|}{ Home visit } & \multicolumn{2}{|c|}{ Discussion during the team's meetings } \\
\hline & $\mathbf{N}^{\circ}$ & $\%$ & $\mathbf{N}^{\circ}$ & $\%$ \\
\hline $\mathrm{CHA}$ & 33 & 57.9 & 24 & 53.3 \\
\hline Nurse & 8 & 14.1 & 8 & 17.8 \\
\hline Physician & 7 & 12.2 & 8 & 17.8 \\
\hline Nursing auxiliary & 8 & 14.1 & 5 & 11.1 \\
\hline Nursing technician & 1 & 1.7 & 0 & 0 \\
\hline Total & 57 & 100 & 45 & 100 \\
\hline
\end{tabular}

The CHA are the workers who most frequently visit cancer patients at home, totaling 33 (57.9\%). These professionals' participation in discussion of cases during team meetings involving cancer patients/families is also observed. Hence, CHA are the professionals who develop the most activities with patients or their families, followed by nurses, physicians and then the remaining nursing professionals. It is worth noting that home visitation is the strategy used by the FHS to remain in contact with patients in their households and $\mathrm{CHA}$ are the main professionals performing this activity; they represent the link with these clientele and aim to identify their health needs ${ }^{(12)}$.

Table 4 presents other care actions performed by the FHT reported by the workers and which were not addressed in the questionnaire (support of caregivers, home visits, discussion in the teams' meetings, technical procedures and consultations). According to workers, making patients welcome is the most frequently performed care action.

Table 4 - Numerical distribution of other care actions performed by workers of the West District FHU toward cancer patients. Ribeirão Preto, SP, Brazil. 2009

\begin{tabular}{lc}
\hline \multicolumn{1}{c}{ Type of provided care } & Total \\
\hline Welcoming & 7 \\
Participation in groups & 6 \\
Referral to other professionals in the team & 4 \\
Offers medical hospital material & 4 \\
Care services are offered to patients & 2 \\
Referral to tertiary level care & 2 \\
Contact complementary services & 4 \\
Provide emotional support to patients & 2 \\
\hline
\end{tabular}

The patients' caregiver is the source of care for this study's workers. The caregiver is usually a family member who accompanies the patient through the different stages of the diagnosis, treatment, rehabilitation and palliative care. Providing this type of care is exhausting to caregivers because it distances them from routine activities, results in financial expenses, deprives them of the social life to which they were accustomed to, and puts them in contact with pain and suffering since cancer is seen as a disease associated with pain, suffering, impairment and death; it is a complex and stigmatizing disease that causes depression, social isolation, and incapacity to work and take part in leisure activities ${ }^{(13)}$.

Emotional support is conceptually linked to affection, empathy, respect and love; appraisal support involves acknowledging the caregiver and/or family member; informational support is related to information, advice, opinion, teaching; and instrumental support is that which make resources, goods and services available ${ }^{(14)}$. Emotional support is the most frequent among the 43 workers followed by informational support for 32 workers, appraisal for 21 workers and instrumental for 17 workers.

A study carried out with 492 caregivers of cancer patients obtained results similar to those of this study in which emotional and informational support became categories that presented the highest number of identified needs(15).

The frequency of care provided to cancer patients through the initiative of FHS workers is: 13 (44.8\%) in FHS units linked to USP and $22(62.9 \%)$ in those linked to the CHD. The frequency of care initiated by 
the search of patients themselves and/or caregivers is $11(37.9 \%)$ in units linked to USP and seven (20.0\%) in those linked to CHD.

An aspect that deserves attention is related to workers' knowledge concerning patients being counterreferred to the FHS unit of origin when the cancer diagnosis was performed in another health unit. It is noteworthy that 20 (74\%) workers in the FHS units linked to USP and $27(77.1 \%)$ workers in units linked to the CHD reported they had no knowledge concerning counter-referred patients. That is, regardless of the ties workers have with units and academic ties, a lack of knowledge concerning counter-referrals was a common element among them. The counter-referral issue is important when one considers integrality of care since the provision of integral care is only possible when it is processed at other points in the care network and the services' users can return to their unit of origin with all the possibilities and commitment of the team to continuity and the longitudinality of care(5). A study(16) addressing the services network for pregnant women in a city in Minas Gerais, Brazil, discusses the coordination of care $^{(5)}$ and identifies a lack of connection between the services network and its users, not acknowledging referrals from specialized care levels, questioning the referrals demand and their real necessity. This finding indicates that basic health care services were devaluing the work of specialized services.

Knowledge concerning the national cancer policy was restricted to nine $(23.1 \%)$ workers in the FHS unit linked to USP and eight (13\%) workers in FHS units linked to CHD. However, only one worker from a unit linked to CHD was able to identify one PNAO objective, which was "to identify the flow of treatment access". In relation to USP, four workers identified four different objectives of this policy ${ }^{(3)}$ : "to improve the flow of treatment access", "improve the flow of diagnosis and referral for treatment", "to promote efficacious screening/prevention of cancer", "right to high-cost medications in the treatment of cancer patients". These data indicate that regardless of the institutional ties of workers, that is, regardless of their connection with USP or CHD, they have little information concerning PNAO and its objectives.

\section{Final Considerations}

The cancer control policy of the Brazilian Ministry of Health seeks to integrate the different health services to provide care to cancer patients and determines that Basic Health Units and the Family Health Strategy are responsible for developing actions directed to the individual and the collective, for establishing actions related to health promotion and cancer prevention; early diagnosis; support for tumor therapy; palliative care; followingup patients undergoing outpatient treatment; sharing information through information subsystems so as to use them in health promotion; developing specialized human resources and promoting the permanent education of professionals involved in the implementation of the cancer control policy.

There is still a long way to go and there are many challenges to overcome. In this study we concluded that some progress was achieved when we consider the Family Health Strategy in Brazil. The care provided by the FHS workers for cancer patients has focused on the disease's emotional and biological aspects, especially in the case of caregivers.

The follow-up of cancer patients is not systematized since even when workers reported knowledge concerning these patients, they reported that no care was provided to them. It draws attention to the fact that even in units in which there is a strong presence of the university responsible for these services, there is not at this point a distinctive practice within the team in relation to the follow-up of these patients. The lack of interconnection among services is apparent in the absence of these patients' counter-referrals, however, there is a prospect for follow-up since it occurs through the initiative of FHT. Workers most frequently reported their own initiative to provide care through activities performed within FHU such as: home visits, discussion of cases in the teams' meetings, consultations, technical procedures, support for caregivers and also activities that involve the work of the FHU and other health levels and sectors, and actions that customize care to cancer patients (seeking rights, guidance concerning side effects of antineoplastic medication).

\section{References}

1. World Health Organization. Union International Against Cancer. Global action against cancer. Geneva: WHO; 2005.

2. Ministério da Saúde (BR). Secretaria de Atenção à Saúde. Instituto Nacional de Câncer. Coordenação de Prevenção e Vigilância de Câncer. Estimativas 2008: Incidência de Câncer no Brasil. Rio de Janeiro: INCA; 2007.
3. Ministério da Saúde [homepage na Internet]. Portaria no 2.439/GM. Política Nacional de Atenção Oncológica. Ministério da Saúde; [acesso em: 8 dezembro 2005].. Brasília. Disponível em http://dtr2001.saude.gov.br/sas/PORTARIAS/Port2005/GM/GM2439.htm. 
4. Ministério da Saúde (BR). Programa de saúde da família. Brasília; 2000.

5. Starfield B. Atenção Primária. Equilíbrio entre necessidades de saúde, serviços e tecnologia. Brasília: UNESCO, Ministério da Saúde; 2002.

6. Santiago SM, Andrade MGG. Avaliação de um programa de controle do câncer cérvico-uterino em rede local de saúde da Região Sudeste do Brasil. Cad Saúde Pública março/abril 2003; 19(2):571-8.

7. Carvalho ECC, Tonani M, Barbora JS. Ações de enfermagem para combate ao câncer desenvolvidas em unidades básicas de saúde de um município do estado de São Paulo. Rev Bras Cancerol outubro/ novembro/dezembro 2005; 51(4):297-303.

8. Lavor MFS. Cuidados paliativos na Atenção Básica: visão dos enfermeiros do Programa Saúde da Família. [dissertação]. Rio de Janeiro (RJ): Universidade Federal do Rio de Janeiro; 2006.

9. cárdenas CP. Atención integral a pacientes oncológicos en la Atención Primaria de Salud. Rev Cubana Med Gen Integ mayo/ junio $2001 ; 17(3)$ :263-7.

10. Teixeira RA, Mishima SM, Pereira MJB. O trabalho de enfermagem em atenção primária à saúde - assistência à saúde da família. Rev Bras Enferm. abril/junho 2000; 53(2):193-206.
11. Ministério da Saúde (BR). Secretaria de Políticas de Saúde, Departamento de Atenção Básica. Avaliação da implantação do programa de saúde da família em dez grandes centros urbanos. Síntese dos principais resultados. Brasília: Ministério da Saúde; 2002.

12. Trapé CA, Soares CB. Educative practice of community health agents analyzed through the category of praxis. Rev. Latino-Am. Enfermagem. janeiro/fevereiro 2007; 15(1):142-9.

13. Maruyama SAT, Zago MMF. The sickening process of colostomy patients by cancer. Rev. Latino-Am. Enfermagem. março/abril 2005; 13(2):216-22.

14. Pedro ICS, Rocha SMM, Nascimento LC. Social support and social network in family nursing: reviewing concepts. Rev. Latino-Am. Enfermagem. março-abril 2008; 16(2):324-7.

15. Floriani CA, Schrmamm FR. Cuidador do idoso com câncer avançado. Um ator vulnerado. Cad Saúde Pública 2006 março; 22(3):527-34.

16. Saúde MIBM. Interrogando a operação da rede de serviços de saúde. [doutorado]. Ribeirão Preto (SP): Escola de Enfermagem de Ribeirão Preto da Universidade de São Paulo; 2006. 